
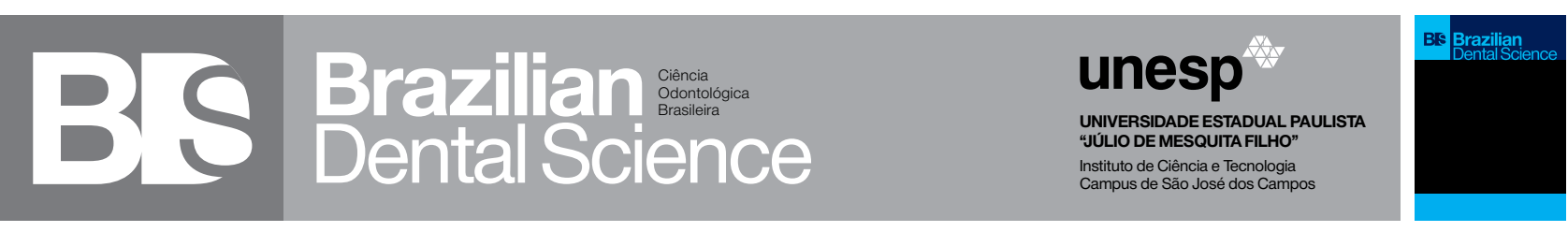

\title{
Surgical treatment of osteonecrosis associated with bisphosphonates: a case report
}

Tratamento cirúrgico da osteonecrose associada a bisfosfonatos: relato de caso

Luisa Machado BARIN ${ }^{1}$, Fernanda Maia PILLUSKY ${ }^{1}$, Raquel Cristine Silva BARCELOS ${ }^{2}$, Carlos Alberto Bazaglia ESCOBAR ${ }^{3}$, Cristiane Cademartori DANESI ${ }^{1}$

1 - Department of Pathology - Federal University of Santa Maria - Santa Maria - RS - Brazil.

2 - Department of Phisiology and Pharmacology - Federal University of Santa Maria - Santa Maria - RS - Brazil.

3 - Department of Stomatology - Federal University of Santa Maria - Santa Maria - RS - Brazil.

\section{ABSTRACT}

Bisphosphonates (BP) are routinely used in the management of metastatic bone diseases and malignancies neoplasms, but there is an adverse effect of their chronic use called bisphosphonaterelated osteonecrosis of the jaw (BRONJ). Treatment for BRONJ is challenging and complex, as there is still no definitive treatment protocols and the various treatments described in the literature have success variables indexes. In this sense, this study aims to emphasize the responsibility of dentist about the knowledge of BRONJ and report a clinical case that the surgical therapy was the best treatment option. Male patient, sixty-nine years old, asked for dental care complaining about bone exposure. On the anamneses, he reported the use of BP due to cancer history. The intra oral examination revealed exposed bone in the lower right molar region extending to retromolar trigon region on lingual side. There was conservative treatment with antibiotic therapy and mouth rinses of chlorhexidine $0.12 \%$, but not obtaining success. Therefore, we opted for the surgical removal of necrotic bone area and the tooth involved. The postoperative was within normal standard. The knowledge of dentist about this pathology is essential to prevent, diagnose and treat this disease the most appropriate way. Although the treatment of BRONJ remains challenging and complex, surgical therapy is a treatment option for lesions in early clinical stages and resistant to conservative treatment, providing a better prognosis and quality of life for the patient.

\section{KEYWORDS}

Bisphosphonate-associated osteonecrosis; Mandible; Oral surgical procedures.

\section{RESUMO}

Os bisfosfonatos (BFs) são rotineiramente usados no manejo de patologias ósseas e neoplasias malignas metastáticas, porém há um efeito adverso de seu uso crônico, denominado osteonecrose da mandíbula associada ao uso de bisfosfonatos (OMAB). O tratamento para OMAB é desafiador e complexo, pois ainda não há protocolos definitivos de tratamento e os inúmeros tratamentos descritos na literatura possuem índices variáveis de sucesso. Neste sentido, este estudo objetiva enfatizar a responsabilidade do cirurgião-dentista no conhecimento da OMAB e relatar um caso clínico em que o tratamento cirúrgico foi a melhor opção terapêutica. Paciente do sexo masculino, 69 anos de idade, procurou atendimento odontológico queixando-se de exposição óssea. $\mathrm{Na}$ anamnese, relatou fazer uso de BFs devido ao histórico de câncer. O exame intraoral revelou exposição óssea em região de molar inferior direito estendendo-se para região de trigonoretromolar pela face lingual. Fez-se o tratamento conservador com antibioticoterapia e bochechos com clorexidina a $0,12 \%$, porém não se obteve sucesso. Assim, optou-se pela remoção cirúrgica da área de necrose óssea e do dente envolvido. O pós-operatório ocorreu dentro dos padrões de normalidade. O conhecimento do cirurgiãodentista sobre esta patologia é essencial para prevenir, diagnosticar e tratar esta doença da forma mais adequada. Embora o tratamento de OMAB permaneça desafiador e complexo, o manejo cirúrgico é uma opção terapêutica para lesões em estágios clínicos iniciais e resistentes ao tratamento conservador, proporcionando um melhor prognóstico e qualidade de vida ao paciente.

\section{PALAVRAS-CHAVE}

Osteonecrose associada a bisfosfonatos; Mandíbula; Procedimentos cirúrgicos bucais. 


\section{INTRODUCTION}

B isphosphonates (BP) are synthetic drugs similar to endogenous pyrophosphate, able to join the bone matrix and to changes in their remodeling [1]. The action mechanism of these drugs is the functional change of osteoclasts and reduction of blood vessels [2]. These drugs are among the ninety most prescribed drugs in the world [3] and they are indicated for treatment of bone diseases and bone metastases associated with soft tissue tumors, providing patients with a significant improvement in quality of life [4].

Despite the undeniable benefit on these patients [4], there is a suggestive adverse effect of their chronic use, so-called the BP-related osteonecrosis of the jaws (BRONJ) [5], which is characterized by spontaneous bone exposure or non-healing wounds, with indolent behavior and difficult to control. For the definitive diagnosis is necessary the simultaneous existence of three factors: use of current or previous BP, presence of necrotic bone in the maxillofacial area, which persists for more than 8 weeks and no local radiotherapy history [6].

There is no consensus in the literature as a standard treatment for BRONJ, making the challenging management of these patients $[7,8]$. In an attempt to guide therapeutic modalities, BRONJ can be classified into three clinical stages: stage 1 , patients with asymptomatic exposed necrotic bone; stage 2 , exposed necrotic bone associated with pain and infection; and stage 3, exposed necrotic bone associated with pain, infection, pathological fracture, extra oral fistula or osteolysis [9]. Based on these stages, conservative therapies are indicated as chlorhexidine $0.12 \%$ mouthrinses (stage 1), antibiotic therapy associated to chlorhexidine $0.12 \%$ mouthrinses (stage 2 ) or more aggressive treatments, such as resection of necrotic bone (stage 3) [6]. In this context, for those who do not respond to conservative treatments, even at early stages, has been recommended surgical treatment [10].

Therefore, the knowledge about the association between BP therapy and the onset of osteonecrosis in gnathic bones is of paramount importance, the health professionals; especially the dentists are responsible to diagnostic and treatment of this disease. This study aims to emphasize the responsibility of health professionals about the knowledge of BRONJ and report a clinical case that the surgical therapy was the best treatment option.

\section{CASE DESCRIPTION}

Male patient, 69 years old, reported to dentist a complaining of bone in asymptomatic mouth exposure in the right mandibular region, after making the endodontic treatment of tooth 46. Besides, in anamnesis, he described be in possession of prostate cancer and make use of the drug zoledronic acid $4 \mathrm{mg}$, via intravenous, administered monthly for approximately one year. Direct oroscopy found exposed bone in the jaw of the right side, accurately on the lingual surface extending from the region of the tooth 46 to trigon retromolar area (Figure 1). The panoramic radiograph analysis showed mild radiolucent area in the mandibular alveolar region distal right to the last tooth (Figure 2).

Considering the reported medical history in the anamnesis and bone exposure observed during the patient clinical examination, the diagnosis was BRONJ at stage 1 . In this way, the dentist opted for conservative therapy employing chlorhexidine mouthwash $0.12 \%$ of two to three times a day. With the progression of the disease, systemic antibiotic therapy was added with the prescription of Amoxicillin 500 $\mathrm{mg}$ of 8 in 8 hours for 8 weeks, but without success in the BRONJ management. Following, the surgical intervention with the extraction of the tooth 46 and bone lingual board resection in the right mandibular region was the treatment chosen by the dentist. The surgical wound that 
still showed necrotic tissue (Figure 3A) was debrided to the onset of bleeding in cancellous bone (Figure 3B). The synthesis was performed using the total closure of the incision (Figure 4) for retail slide in order to promote wound healing by first intention. As adjunctive therapy, in the preoperative period, was used chlorhexidine $0.12 \%$ mouthwash for 1 minute and irrigation of the surgery site with the same solution. In addition, the antibiotic therapy was initiated 2 hours before the procedure with Clindamycin $300 \mathrm{mg}, 1$ tablet 8 in 8 hours for 4 weeks. Macroscopically, bone lingual board (1.5 x 1.0 $\mathrm{x} 0.7 \mathrm{~cm}$ ) was presented, in part, adhered to the dental piece (Figure 5). The collected material was submitted to histopathological evaluation, which showed the presence of numerous bacterial lumpy masses associated with polymorph nuclear leukocytes and neutrophils in filling small cavities devitalized bone, confirming the process of osteonecrosis (Figure 6).

The process of postoperative healing occurs within the normal range, as evidenced by control in 2 weeks (Figure 7). After three years of monitoring, new clinical examination (Figure 8) and radiographic (Figure 9) was performed, demonstrating bone repair of the affected area by the osteonecrosis. The clinical examination showed a healthy mucosa without bone exposure in the operated area, demonstrating complete repair of the exposed bone injury. The patient is being treated for prostate cancer with pamidronate and abiraterone acetate interspersed administrations. The dentist referred the patient for prosthetic rehabilitation and maintains periodic consultations for dental reviews.

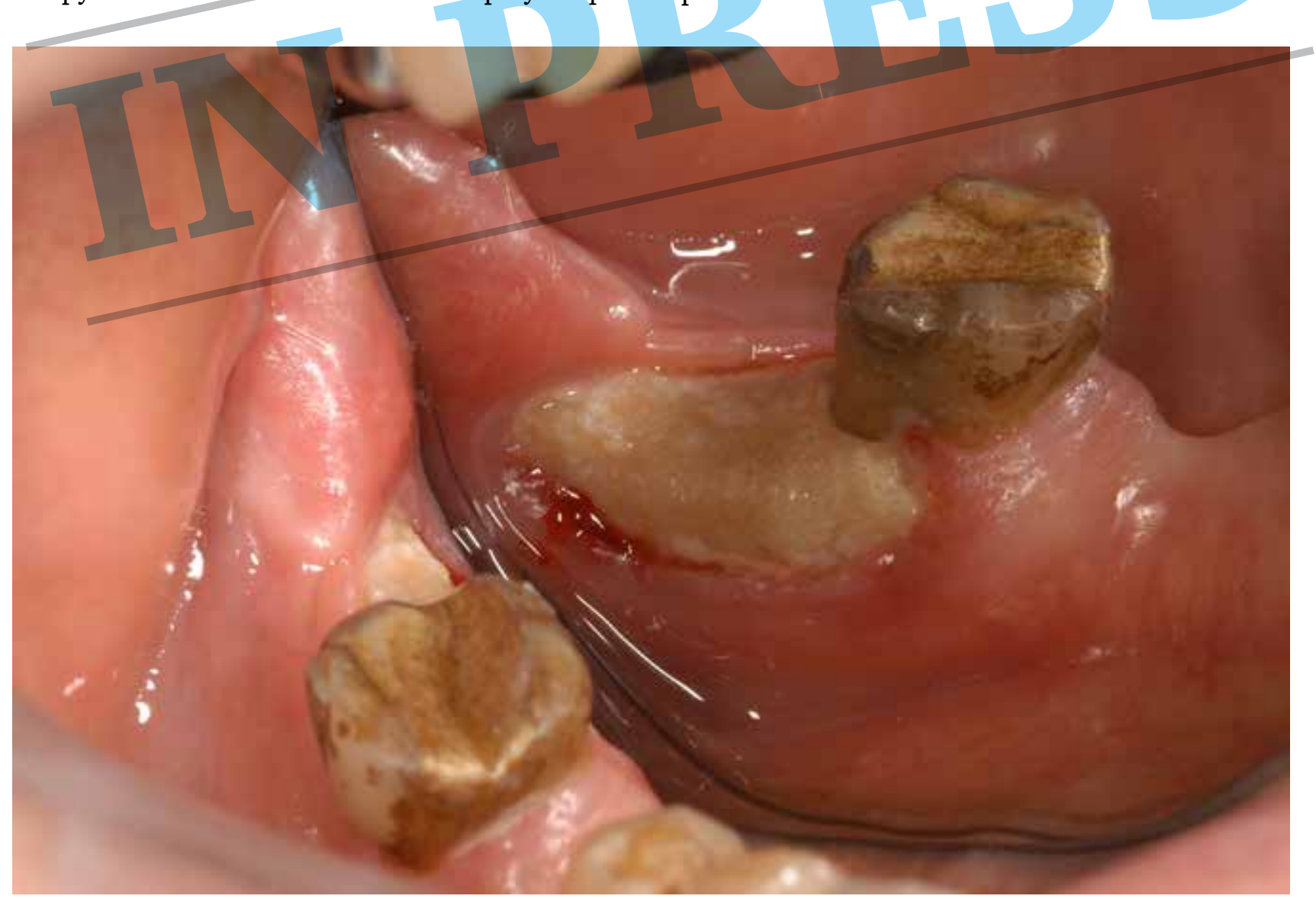

Figure 1 - Bone exposure area in the retromolar trigon region, lingual, reflected in the mirror. 


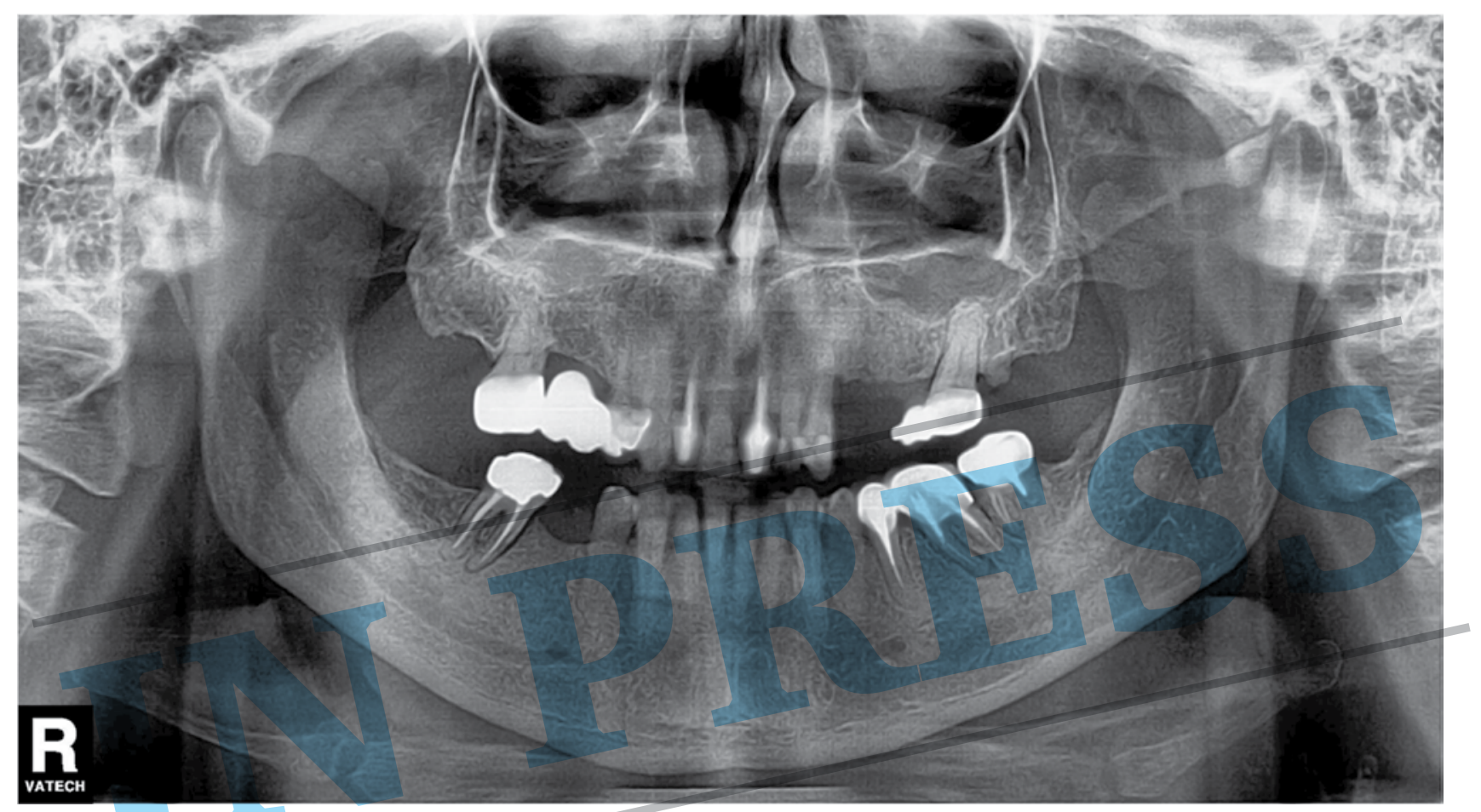

Figure 2 - Soft bone thinning in the distal region of the tooth 46.

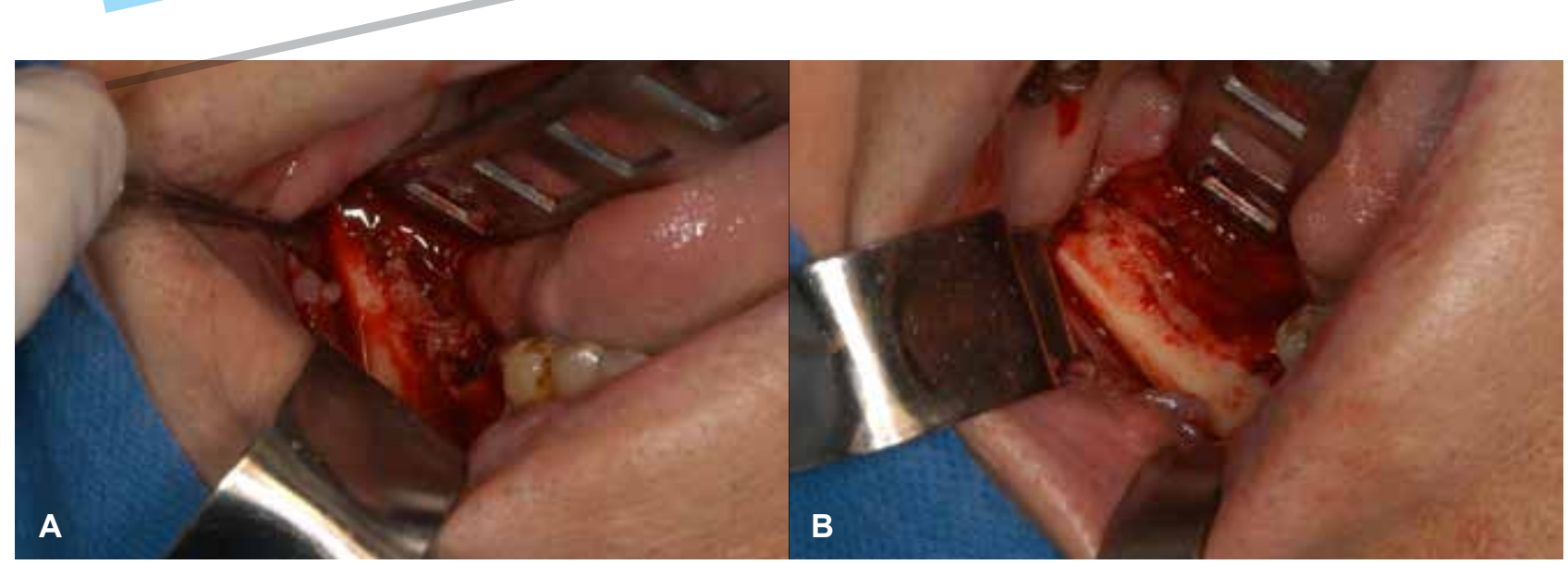

Figure 3 - a) Presence of the necrotic tissue; b)After debridement of the affected area. 


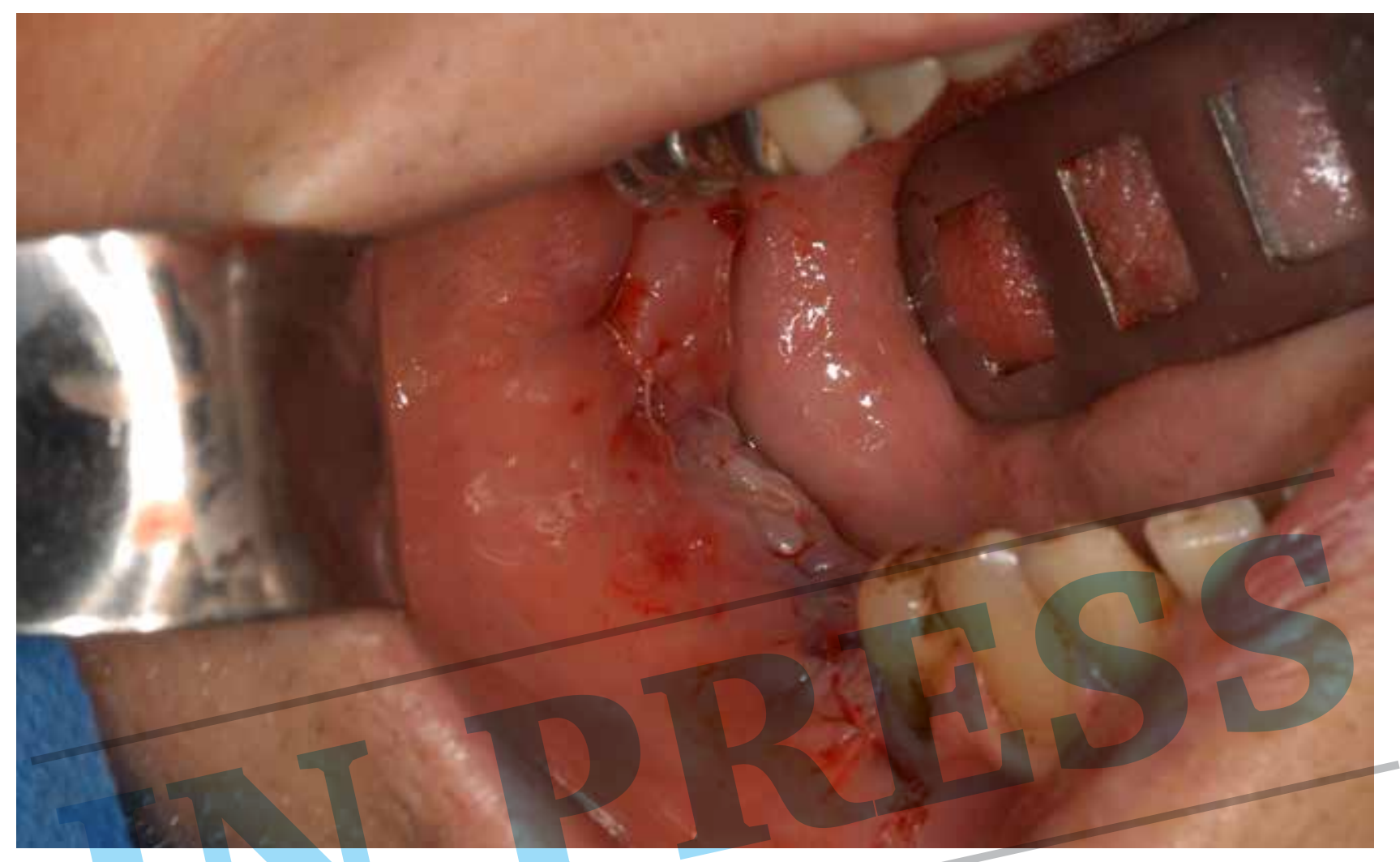

Figure 4 - Wound closure with simple stitches and absorbable sutures.

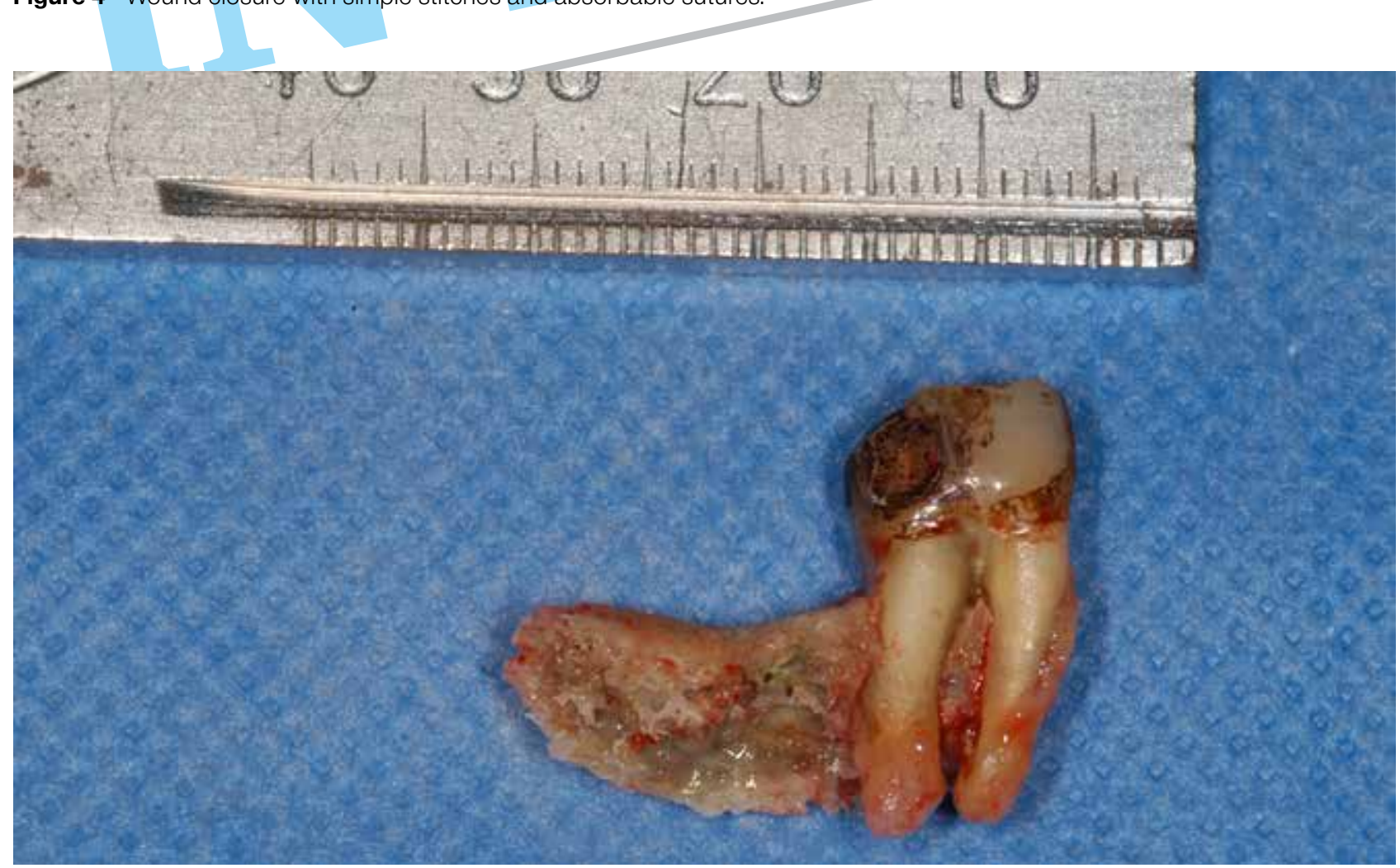

Figure 5 - Bone and tooth board 46 seen from the buccal region. 


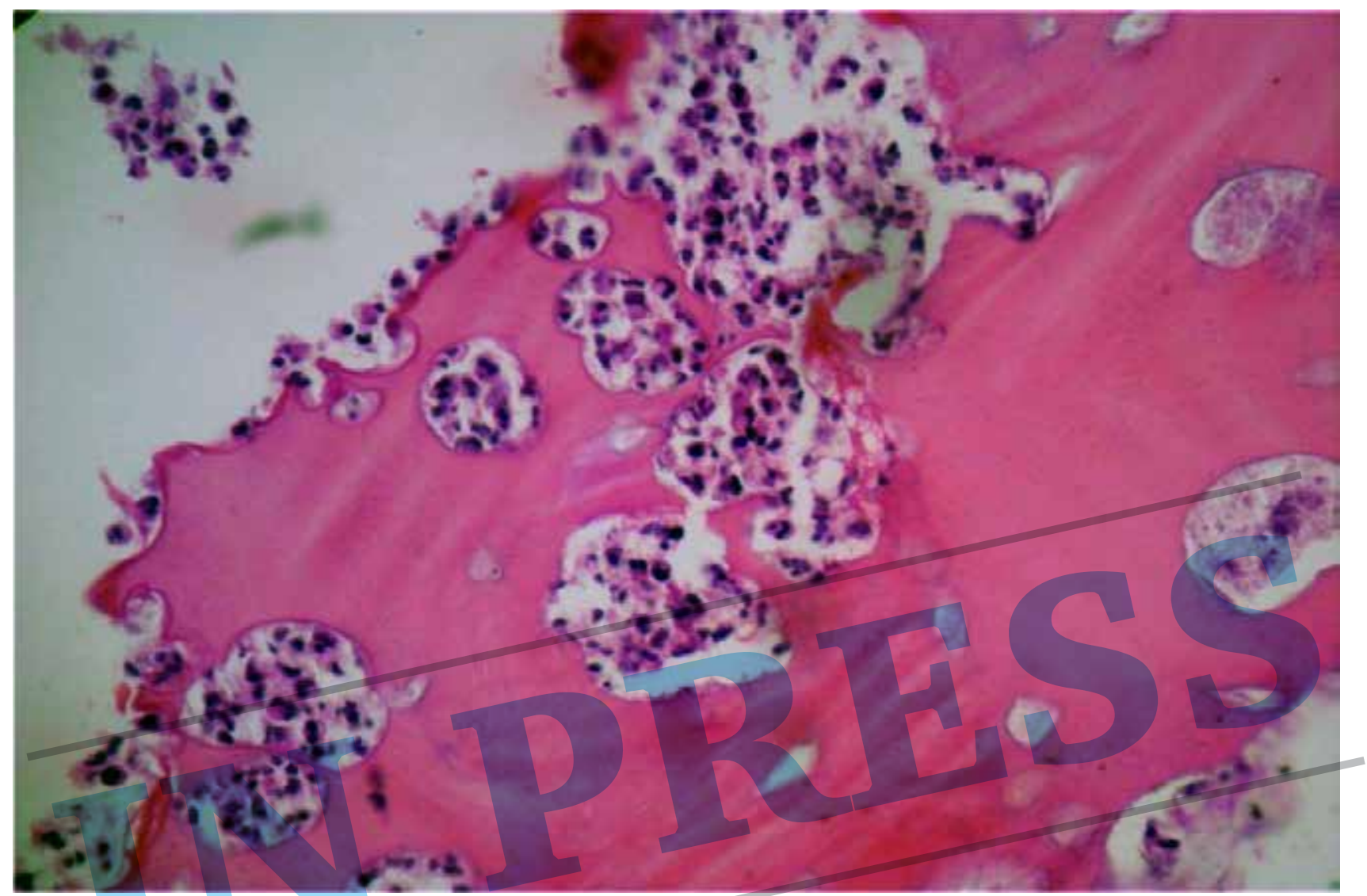

Figure 6 - Neutrophils filling small bone cavities.

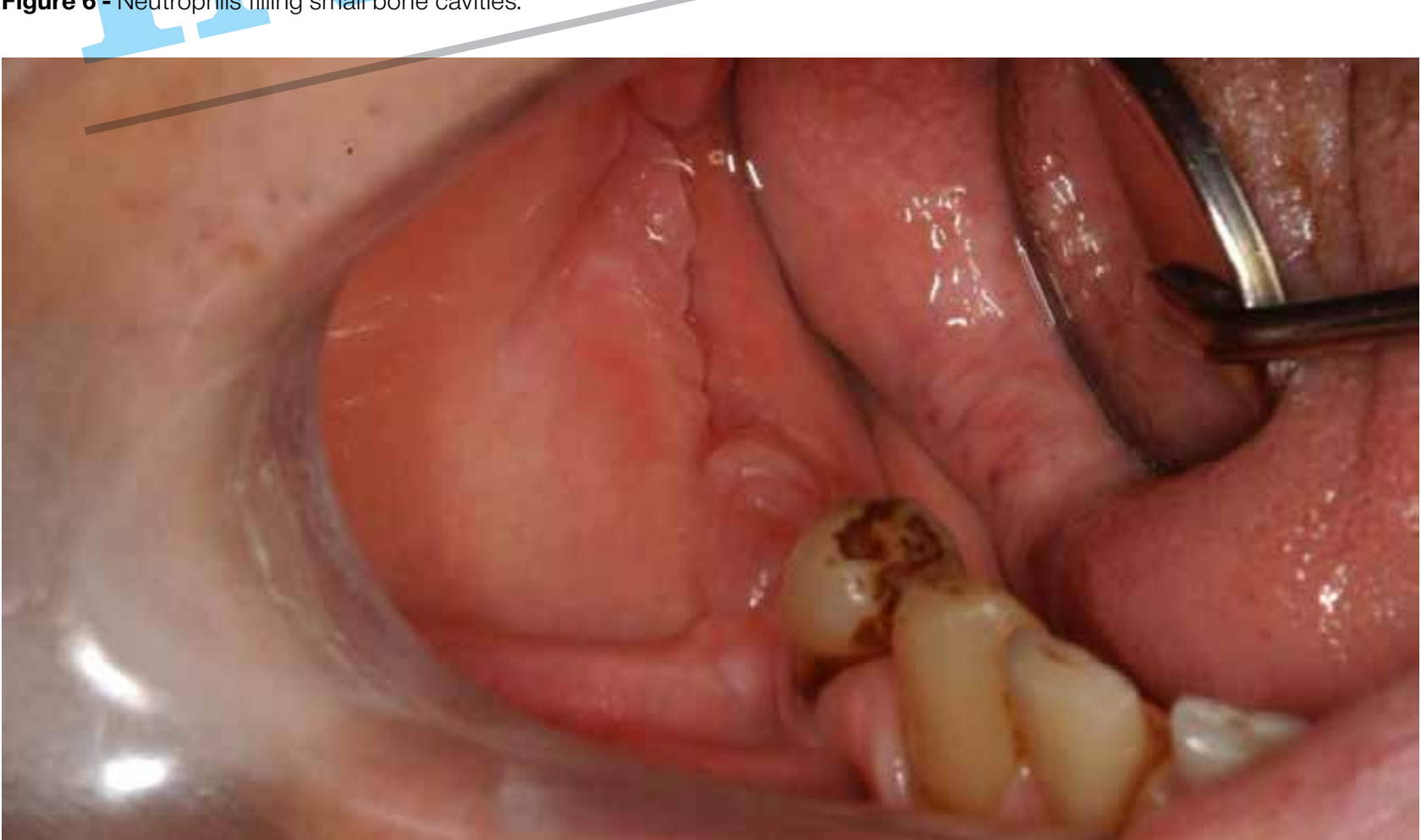

Figure 7 - Wound healing aspects in period of 2 weeks. 


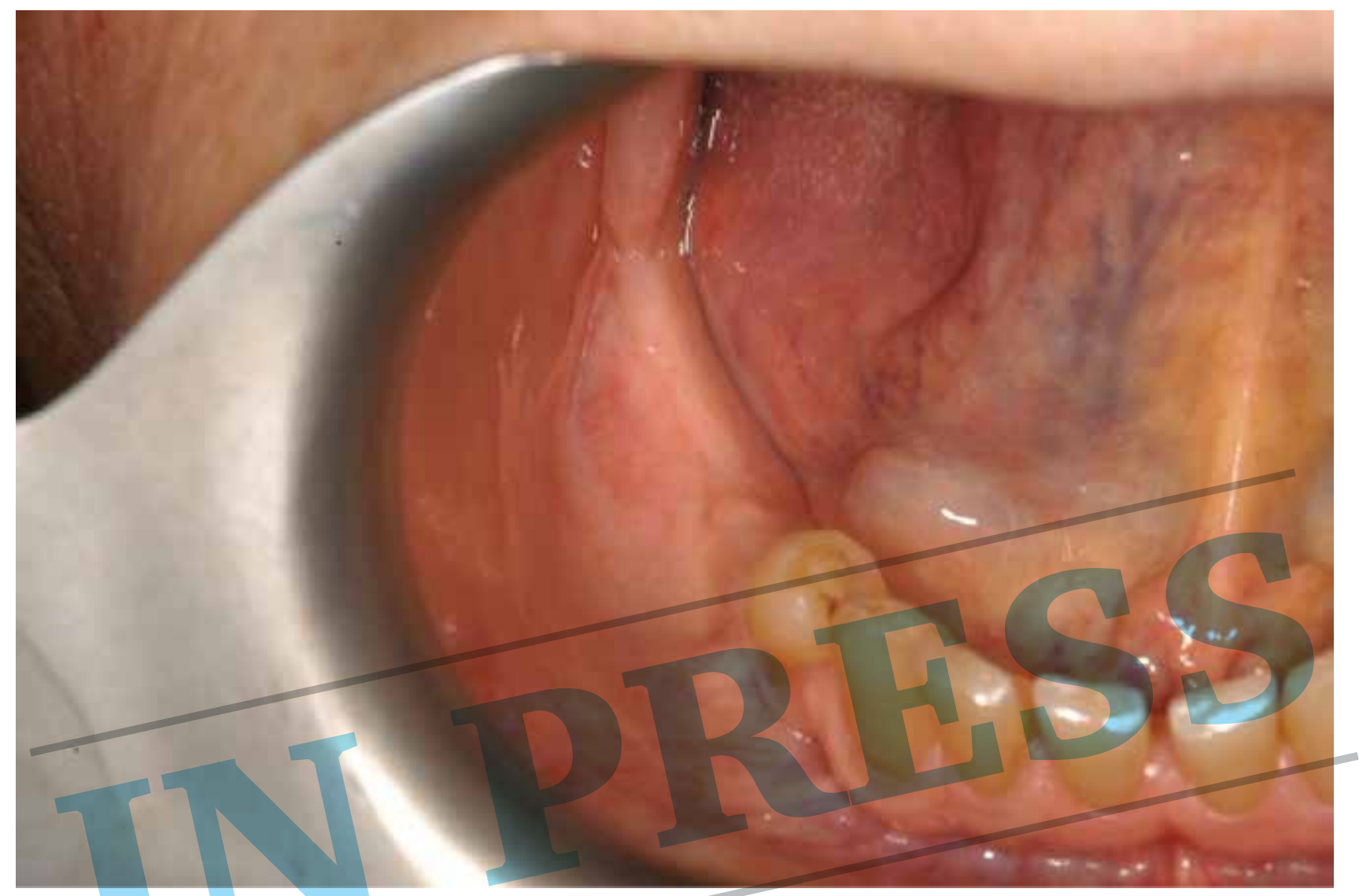

Figure 8 - Region mucosa after 3 years of follow-up.

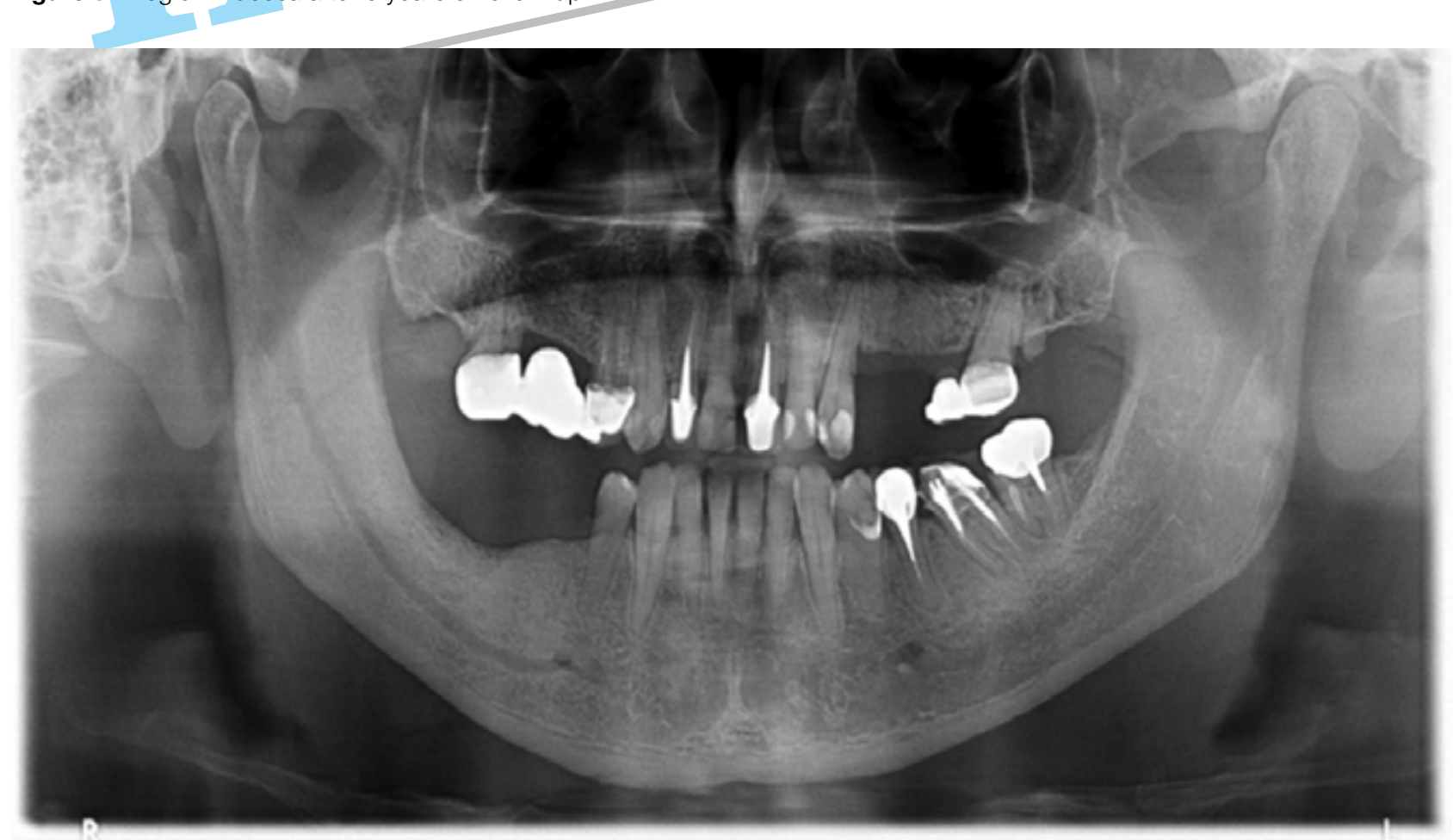

Figure 9 - Radiographic control 3 years of age surgical intervention. 


\section{DISCUSSION}

The literature suggests that $\mathrm{BP}$ chronic use can raise in a serious adverse effect: BRONJ [5]. Its occurrence is almost exclusive to gnathic bones, possibly because the oral cavity is subject to constant trauma from jaw movements, and by direct contact with several pathogenic microorganisms [11]. Added to this fact, there is still inadequate bone response to metabolic demands due to the presence of $\mathrm{BP}$, which alters the bone remodeling and favors avascular necrosis, culminating in the appearance of osteonecrosis $[1,2]$.

There is an important discussion about the causal association between the use of BP and the onset of osteonecrosis in patients previously submitted to extractions. This dental procedure is cited as the main local risk factor for BRONJ, followed by trauma and behaviors that lead to bone damage [12]. In this case, the patient underwent endodontic procedure prior to BRONJ, suggesting that local trauma by the instrumentation or even the clamp pressure in the mucosa during the complete isolation procedure, which may have been the cause for the development of osteonecrosis. In this context, it becomes eminent responsibility of health professionals, especially the dentist in the search for knowledge about the current theme, in planning their activities in choosing elective procedures, as well as the minimization of any factor that may induce the osteonecrosis.

About the osteonecrosis clinical features, the jaw presents how most common site, mainly the lingual surfaces of the posterior region and thin mucosa areas over bony prominences [13]. The average age for its manifestation occurs around 66 years and mainly affects females [7]. The present study shows similar data for predominant location and age, but occurs in a male patient. A plausible explanation for the increased number of diagnoses occur in women, due the increase in annual incidence of osteoporosis [14] and hence the large BP prescription for its treatment [3]. The higher frequency of multiple myeloma and breast cancer in women may also explain the higher incidence of osteonecrosis in this sex [15].

The BP intravenous administration appears to confer a greater risk than oral administration, since that intravenous BP are more potent and have greater bioavailability compared to oral use. About $50 \%$ of intravenous $\mathrm{BP}$ is bioavailable for incorporation into the bone matrix, while that in via oral BP $1 \%$ on average is embedded in the bone [16]. Additionally, treatment time with BP also has influence in the BRONJ appearance, so, as longer the treatment time, the risk of osteonecrosis increases [17]. Marx et al [5] showed that the average time from onset of lesions ranged from 9 to 14 months for patients who were intravenous therapy with pamidronate or zoledronic acid, and three years in patients taking alendronate for osteoporosis treatment. In our study, the patient used the zolendronic acid intravenously for approximately one year, which was enough time to onset of osteonecrosis, corroborating with literature findings.

Since 2003, BRONJ treatment is a source of concern for the dental area [18], provided that there is no definitive treatment protocols and the various treatments described in the literature have indexes success variables $[7,8]$. Accordingly, the classification stages of the disease can guide therapeutic choices [6,9], but the general health of the patient and the degree of biological response should be carefully evaluated by defining the choice of treatment, regardless of the clinical stage diagnosed.

In general, there is a strong tendency for more conservative treatments, which have a lower risk of bone exposure, edema, pain and bleeding [7, 19, 20], with the disadvantage of being a continuous therapy, may further weaken the patient systemic condition, and sometimes not get the stagnation, regression or the resolution of the lesion. However, the literature have demonstrated excellent results for more invasive approaches [21-23], with data rates 
of $90 \%$ success [24]. The surgical management has been proposed for cases where conservative treatment is unsuccessful or even as a top choice therapy $[10,25]$. Our study presents a BRONJ at stage 1 , for which initially applied a conservative therapy (mouthwash associated with systemic antibiotics) and lasting, not getting response; we opted for surgical intervention, which led to the case resolution. Thus, we confirm the healing findings by a more invasive technique contributing to the current literature through another example for the BRONJ management. On the other hand, remains the question whether the election of surgical treatment as a first option could provide an even better prognosis for this patient, with more rapid remission of the lesion and reduced antibiotics prescription.

Based on the presented case report and literature, we can conclude that the osteonecrosis of the jaws associated with the BP use is a serious complication; it can be harmful to the patient, besides being management difficult in the dental clinic. The knowledge of dentist about this pathology is essential to prevent, diagnose and treat this disease the most appropriate way. Although the treatment of BRONJ remains challenging and complex, surgical therapy is a treatment option for lesions in early clinical stages and resistant to conservative treatment, providing a better prognosis and quality of life for the patient.

\section{REFERENCES}

1. Migliorati CA, Casiglia J, Epstein J, Jacobsen PL, Siegel MA, Woo S-B. Managing the care of patients with bisphosphonateassociated osteonecrosis: an American Academy of Oral Medicine position paper. J Am Dent Assoc. 2005 Dec;136(12):1658-68. [Medline:16383047]

2. Yin G, Bai Y, Luo E. Angiogenic suppression of osteoclasts may play a role in developing bisphosphonate-related osteonecrosis of the jaw. Med Hypotheses. 2011 Mar;76(3):347-9. doi:10.1016/j.mehy.2010.10.036

3. Marketos M. The top 200 brand drugs in 2003 (by units). Drug Topics Advanstar Communications Inc; 2004 Mar;148(76).

4. Lopes B, Xisto R, Lordani F, Alves J, Rocha R, Machado W, et al. Use of bisphosphonates in patients with cancer and its association with osteonecrosis of the maxillary bones - a literature review. Rev Periodontia. 2010;20(3):20-7.
5. Marx RE, Sawatari Y, Fortin M, Broumand V. Bisphosphonate induced exposed bone (osteonecrosis/osteopetrosis) of the jaws: risk factors, recognition, prevention, and treatment. J Oral Maxillofac Surg. 2005 Nov;63(11):1567-75. doi:10.1016/j. joms.2005.07.010.

6. Ruggiero SL, Dodson TB, Assael LA, Landesberg R, Marx RE, Mehrotra B. American Association of Oral and Maxillofacial Surgeons position paper on bisphosphonate-related osteonecrosis of the jaws--2009 update. J Oral Maxillofac Surg. 2009 May;67(5):2-12. doi:10.1016/j.joms.2009.01.009.

7. Fliefel R, Tröltzsch M, Kühnisch J, Ehrenfeld M, Otto S. Treatment strategies and outcomes of bisphosphonate-related osteonecrosis of the jaw (BRONJ) with characterization of patients: a systematic review. Int J Oral Maxillofac Surg. 2015 Feb;44(5):568-85. doi:10.1016/j.ijom.2015.01.026.

8. Kühl S, Walter C, Acham S, Pfeffer R, Lambrecht JT. Bisphosphonate-related osteonecrosis of the jaws--a review. Oral Oncol. 2012 0ct;48(10):938-47. doi:10.1016/j. oraloncology.2012.03.028.

9. Estilo CL, Van Poznak CH, Wiliams T, Bohle GC, Lwin PT, Zhou $Q$, et al. Osteonecrosis of the maxilla and mandible in patients with advanced cancer treated with bisphosphonate therapy. Oncologist. 2008 Aug;13(8):911-20. doi:10.1634/ theoncologist.2008-0091.

10. Vescovi P, Manfredi M, Merigo E, Meleti M. Early surgical approach preferable to medical therapy for bisphosphonaterelated osteonecrosis of the jaws. J Oral Maxillofac Surg. 2008 Apr;66(4):831-2. doi:10.1016/j.joms.2007.11.025

11. Assael LA. A time for perspective on bisphosphonates. J Oral Maxillofac Surg. 2006 Jun;64(6):877-9. doi:10.1016/j. joms.2006.04.003.

12. Nisi M, La Ferla F, Karapetsa D, Gennai S, Miccoli M, Baggiani $A$, et al. Risk factors influencing BRONJ staging in patients receiving intravenous bisphosphonates: a multivariate analysis. Int J Oral Maxillofac Surg. 2015 Feb;44(5):586-91. doi:10.1016/j.ijom.2015.01.014.

13. Almăşan HA, Băciuţ M, Rotaru H, Bran S, Almăşan OC, Băciuţ G. Osteonecrosis of the jaws associated with the use of bisphosphonates. Discussion over 52 cases. Rom J Morphol Embryol. 2011 Jan;52(4):1233-41.

14. López-D’alessandro E, Mardenlli F, Paz M. Oral bisphosphonateassociated osteonecrosis of maxillary bone: A review of 18 cases. J Clin Exp Dent. 2014 Dec;6(5):530-4. doi:10.4317/ jced.51694.

15. Bilezikian JP. Osteonecrosis of the jaw--do bisphosphonates pose a risk? N Engl J Med. 2006 Nov;355(22):2278-81. doi:10.1056/NEJMp068157.

16. Ezra A, Golomb G. Administration routes and delivery systems of bisphosphonates for the treatment of bone resorption. Adv Drug Deliv Rev. 2000 Aug;42(3):175-95.

17. Ruggiero SL, Fantasia J, Carlson E. Bisphosphonate-related osteonecrosis of the jaw: background and guidelines for diagnosis, staging and management. Oral Surg Oral Med Oral Pathol Oral Radiol Endod. 2006 0ct;102(4):433-41. doi:10.1016/j. triple0.2006.06.004.

18. Ruggiero S, Gralow J, Marx RE, Hoff AO, Schubert MM, Huryn JM, et al. Practical guidelines for the prevention, diagnosis, and 
treatment of osteonecrosis of the jaw in patients with cancer. J Oncol Pract. 2006 Jan;2(1):7-14.

19. Gómez-Moreno G, Arribas-Fernández MC, Fernández-Guerrero M, Boquete-Castro A, Aguilar-Salvatierra A, Guardia J, et al. Bisphosphonate-associated osteonecrosis of the jaw 2 years after teeth extractions: a case report solved with non-invasive treatment. Eur Rev Med Pharmacol Sci. 2014 Jan;18(9):1391-7.

20. Polymenidi I, Trombetti A, Carballo S. The risk of bisphosphonate-related osteonecrosis of the jaw. Rev Med Suisse. 2014 0ct;10(446):1930-4.

21. Altay MA, Tasar F, Tosun E, Kan B. Low-Level Laser Therapy Supported Surgical Treatment of Bisphosphonate Related 0steonecrosis of Jaws: A Retrospective Analysis of 11 Cases. Photomed Laser Surg. 2014 Jul;32:468-75. doi:10.1089/ pho.2014.3742.

22. Anitua E, Begoña L, Orive G. Treatment of hemimandibular paresthesia in a patient with bisphosphonate-related osteonecrosis of the jaw (BRONJ) by combining surgical resection and PRGF-Endoret. Br J Oral Maxillofac Surg. 2013 Dec;51(8):272-4. doi:10.1016/j.bjoms.2012.08.018.
23. Franco S, Miccoli S, Limongelli L, Tempesta A, Favia $\mathrm{G}$, Maiorano $\mathrm{E}$, et al. New dimensional staging of bisphosphonate-related osteonecrosis of the jaw allowing a guided surgical treatment protocol: long-term follow-up of 266 lesions in neoplastic and osteoporotic patients from the university of bari. Int J Dent. 2014 Jan;2014:935657. doi:10.1155/2014/935657.

24. Ristow 0, Otto S, Troeltzsch M, Hohlweg-Majert B, Pautke C. Treatment perspectives for medication-related osteonecrosis of the jaw (MRONJ). J Craniomaxillofac Surg. 2015 Mar;43(2):290-3. doi:10.1016/j.jcms.2014.11.014.

25. Melea PI, Melakopoulos I, Kastritis E, Tesseromatis C, Margaritis V, Dimopoulos $\mathrm{M}$ a, et al. Conservative treatment of bisphosphonate-related osteonecrosis of the jaw in multiple myeloma patients. Int J Dent. 2014;2014:427273. doi: 10.1155/2014/427273. Epub 2014 Jun 17.

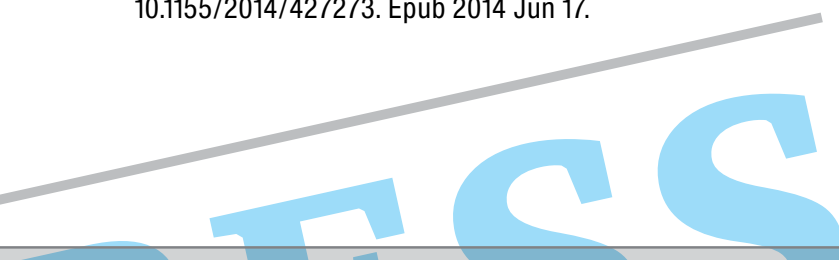

Luisa Machado Barin (Corresponding address)

Departamento de Patologia, Universidade Federal de Santa Maria Av. Roraima, 1000, 97105-900 Santa Maria, prédio 20, sala 4013 Santa Maria, Rio Grande do Sul, Brasil

Phone: +55-55-99628-3888 Fax. +55-55-32208141 E-mail: luisabarin@hotmail.com / luisambarin@gmail.com

Date submitted: 2017 Jan 13 Accept submission: 2017 Mar 20 